\title{
ENaC activity in collecting ducts modulates NCC in cirrhotic mice
}

\author{
David Mordasini ${ }^{1,2} \cdot$ Dominique Loffing-Cueni $^{5} \cdot$ Johannes Loffing $^{5}$. \\ Rohrbach Beatrice $^{1,2}$ - Marc P. Maillard ${ }^{3}$. Edith Hummler ${ }^{4}$. \\ Michel Burnier $^{3} \cdot$ Geneviève Escher $^{1,2} \cdot$ Bruno Vogt $^{1,2}$
}

Received: 27 January 2015 /Revised: 24 April 2015 / Accepted: 18 May 2015 / Published online: 10 June 2015

(C) Springer-Verlag Berlin Heidelberg 2015

\begin{abstract}
Cirrhosis is a frequent and severe disease, complicated by renal sodium retention leading to ascites and oedema. A better understanding of the complex mechanisms responsible for renal sodium handling could improve clinical management of sodium retention. Our aim was to determine the importance of the amiloride-sensitive epithelial sodium channel $(\mathrm{ENaC})$ in collecting ducts in compensate and decompensate cirrhosis. Bile duct ligation was performed in control mice (CTL) and collecting duct-specific $\alpha \mathrm{ENaC}$ knockout (KO) mice, and ascites development, aldosterone plasma concentration, urinary sodium/potassium ratio and sodium transporter expression were compared. Disruption of $\mathrm{ENaC}$ in collecting ducts (CDs) did not alter ascites development, urinary sodium/potassium ratio, plasma aldosterone concentrations or $\mathrm{Na}, \mathrm{K}-\mathrm{ATPase}$ abundance in CCDs. Total $\alpha \mathrm{ENaC}$ abundance in whole kidney increased in cirrhotic mice of both genotypes and cleaved forms of $\alpha$ and $\gamma$
\end{abstract}

Geneviève Escher and Bruno Vogt contributed equally to the work

David Mordasini

david.mordasini@dkf.unibe.ch

1 Department of Nephrology, Hypertension and Clinical Pharmacology, Inselspital, Bern University Hospital, Bern, Switzerland

2 Department of Clinical Research, University of Bern, Bern, Switzerland

3 Service of Nephrology and Hypertension, CHUV, Rue du Bugnon 17, CH-1005 Lausanne, Switzerland

4 Department of Pharmacology and Toxicology, University of Lausanne, Rue du Bugnon 27, CH-1005 Lausanne, Switzerland

5 Institute of Anatomy, University of Zurich, Zurich, Switzerland
$\mathrm{ENaC}$ increased only in ascitic mice of both genotypes. The sodium chloride cotransporter (NCC) abundance was lower in non-ascitic $\mathrm{KO}$, compared to non-ascitic CTL, and increased when ascites appeared. In ascitic mice, the lack of $\alpha \mathrm{ENaC}$ in $\mathrm{CDs}$ induced an upregulation of total $\mathrm{ENaC}$ and $\mathrm{NCC}$ and correlated with the cleavage of $\mathrm{ENaC}$ subunits. This revealed compensatory mechanisms which could also take place when treating the patients with diuretics. These compensatory mechanisms should be considered for future development of therapeutic strategies.

Keywords Ascites $\cdot$ Aldosterone $\cdot$ Cirrhosis $\cdot$ Cortical collecting ducts $\cdot \mathrm{ENaC} \cdot \mathrm{NCC}$

\section{Introduction}

Cirrhosis is a frequent and severe disease, complicated by renal sodium retention leading to ascites and oedema. The development of the disease starts with damages to the liver architecture causing an increase of intrahepatic resistance and leading to portal hypertension. The latter is known to stimulate the production of nitric oxide, which, in turn, induces a peripheral arterial vasodilatation and causes intravascular volume insufficiency. This triggers mechanisms of sodium and water conservation through the renin-angiotensin system, the sympathetic nervous system and the vasopressin pathway. It is hypothesized that an inadequate stimulation of these pathways leads to renal sodium retention which will favour ascites accumulation $[13,25]$. However, cellular and molecular mechanisms responsible for unbalanced renal sodium transport are incompletely understood.

We showed previously that bile duct-ligated mice developed ascites concomitantly to $\mathrm{Na}, \mathrm{K}$-ATPase stimulation in cortical collecting ducts exclusively [1]. Underlining the role 
of the aldosterone-sensitive distal nephron in ascites development, studies performed with rats showed an increased apical targeting of $\mathrm{ENaC}$ in ascitic animals [20,21]. In order to investigate the role of collecting ducts (CDs) in cirrhosisinduced sodium retention, we used a transgenic mouse model with a CD-specific inactivation of the amiloride-sensitive sodium channel $(\mathrm{ENaC})$ [30], which is crucial for regulated renal sodium reabsorption. Rubera et al. showed that mice with disruption of $\alpha \mathrm{ENaC}$ in $\mathrm{CDs}$ were still able to maintain sodium and potassium balance, even when challenged by salt restriction, water deprivation or potassium loading [30]. Our hypothesis was that in pathological conditions, such as cirrhosis, CD function may become of importance.

The aim of the present study was to determine the importance of $\mathrm{ENaC}$ in $\mathrm{CDs}$ using the bile duct ligation-induced cirrhosis mouse model. We investigated ascites development, plasma aldosterone concentrations, urinary sodium and potassium excretion, as well as the abundance of $\mathrm{ENaC}$ subunits, $\mathrm{Na}, \mathrm{K}-\mathrm{ATP}$ ase and sodium chloride cotransporter (NCC) in control (CTL) and $\alpha \mathrm{ENaC} \mathrm{KO} \mathrm{(KO)} \mathrm{mice.}$

\section{Subjects and methods}

\section{Animals}

Animal studies were approved by the Veterinary Service of the Canton de Vaud, Switzerland. Experiments were performed on adult CTL $\left(\right.$ Scnn $\left.1 a^{\text {lox/lox }}\right)$ and $\alpha \mathrm{ENaC} \mathrm{KO}$ (Hoxb7::crel scnn $\left.1 a^{\text {lox/lox }}\right)$ mice.

\section{Bile duct ligation}

The bile duct ligation was performed under anaesthesia mediated by isoflurane inhalation (57 CTL and $53 \mathrm{KO}$ ). A ventral incision was made; ligatures were tightened around the bile duct and the segment in between excised. The same procedure was performed in SHAM-operated mice (12 CTL and $10 \mathrm{KO}$ ) except that no ligatures were tightened. After ligation, abdominal muscles were sutured and skin closed with Michel's suture clips. Mice were observed daily and received paracetamol (200 mg/kg/day) in drinking water for 2 days following surgery.

\section{Ascites quantitation}

Ascites development was monitored by body weight measurement. Groups were determined a posteriori at the time of sacrifice. Mice with ascites at the time of sacrifice were included in BDL + group and the other in BDL-. The rate of ascites accumulation was estimated by the calculation of bodyweight difference between a measurement and the previous one.

\section{Plasma aldosterone concentrations}

Plasma aldosterone concentrations were measured by RIA (Coat-a-Count; Diagnostics Products Inc.).

\section{Immunostaining}

Kidneys of anesthetized mice were fixed for 5 min with $3 \%$ PFA in phosphate buffer by retrograde perfusion via the abdominal aorta [22]. Kidneys were cut in thin sections, frozen in liquid propane and stored at $-80{ }^{\circ} \mathrm{C}$ until further analysis. Immunohistochemistry was performed on $4 \mu \mathrm{m}$ cryosections. Sections were blocked with $10 \%$ normal goat serum and subsequently incubated over night at $4{ }^{\circ} \mathrm{C}$ with the primary antibodies (N-ter $\alpha \mathrm{ENaC} 1 / 5000$ [33]); followed by a Cy3conjugated donkey anti-rabbit IgG (Jackson Immuno Research Laboratories) diluted 1/1000. The sections were analysed by a fluorescence microscope (Leica). Pictures were taken with a CCD camera and processed with Adobe Photoshop and Microsoft PowerPoint softwares.

\section{Urine collection}

Mice were installed into restraining tube, every 3 to 4 days from 8:00 am to 11:00 am, for urine collection. Urinary sodium and potassium were measured by flame photometry (IL943, Instrumentation Laboratory).

\section{Microdissection of renal tubules}

The left kidney was perfused with a liberase-containing solution (liberase TM $33 \mu \mathrm{g} / \mathrm{ml}$ from Roche in Dulbecco's modified Eagle's medium: Nutrient Mixture F-12 (DMEM/F12), 21041-025; Gibco). Pyramids cut along the corticomedullary axis were incubated at $30{ }^{\circ} \mathrm{C}$ for $40 \mathrm{~min}$ in perfusion medium. Tubules were isolated in ice-cold DMEM/F-12 supplemented with $0.05 \%$ BSA without liberase. Tubules were transferred into 96-well plates and photographed. The total length of tubules was measured using Image $\mathbf{J}$ [32].

\section{Na,K-ATPase assay}

$\mathrm{Na}, \mathrm{K}$-ATPase activity was determined as previously described [5]. Total ATPase activity was determined in a solution containing $50 \mathrm{mM} \mathrm{NaCl}, 5 \mathrm{mM} \mathrm{KCl}, 10 \mathrm{mM} \mathrm{MgCl} 2,1 \mathrm{mM}$ EGTA, $100 \mathrm{mM}$ Tris-HCl, $10 \mathrm{mM} \mathrm{Na}{ }_{2}$ ATP and $8 \mathrm{nCi} / \mu \mathrm{l}$ of ATP $\left[\gamma-{ }^{32} \mathrm{P}\right](10 \mathrm{Ci} / \mathrm{mmol}, 2 \mathrm{mCi} / \mathrm{ml}$, Perkin Elmer: BLU002250UC) at $\mathrm{pH}$ 7.4. For $\mathrm{Na}^{+}, \mathrm{K}^{+}$-independent ATPase activity measurements, $\mathrm{NaCl}$ and $\mathrm{KCl}$ were omitted, Tris- $\mathrm{HCl}$ was $150 \mathrm{mM}$, and $2 \mathrm{mM}$ ouabain was added. Na,K-ATPase activity was taken as the difference between total and $\mathrm{Na}^{+}, \mathrm{K}^{+}$independent ATPase activities and expressed as the mean in $\mathrm{pmole} / \mathrm{mm} / \mathrm{h}$ of $n$ measurements. 
Table 1 Primers and probe number used for $\mathrm{qPCR}$

\begin{tabular}{|c|c|c|c|}
\hline Gene & Forward primer & Reverse primer & Probe \\
\hline scnn1a & CCAAGGGTGTAGAGTTCTGTGA & AGAAGGCAGCCTGCAGTTTA & 45 \\
\hline scnn1b & TTCAACTGGGGCATGACAG & CCGATGTCCAGGATCAACTT & 29 \\
\hline scnn1g & AACAGAGAAAACGCCACCAT & TTATGTATAAGATGACTTGCAGACCA & 16 \\
\hline slc12a3 & CСТCCATCACCAACTCACCT & CCGCCCACTTGCTGTAGTA & 12 \\
\hline
\end{tabular}

\section{SDS-PAGE and immunoblotting}

Kidneys were homogenized using a Dounce tissue grinder and membrane proteins extracted in the presence of protease and phosphatase inhibitors (No. 78440, Pierce) according to the manufacturer's protocol (MEM Per Plus Kit No. 89842 , Pierce). Protein concentration was quantified using the BCA protein assay kit (No. 23225, Pierce). Ten micrograms was separated by SDS-PAGE, then transferred on nitrocellulose membrane and stained with Ponceau red before immunodetection. Nitrocellulose membranes were incubated with primary antibodies detecting $\alpha \mathrm{ENaC}(1 / 10,000)[33]$, $\beta \mathrm{ENaC}(1 / 10,000)[34]$ and $\gamma \mathrm{ENaC}(1 / 10,000)[34]$ and NCC $(1 / 10,000)$ [33]. Immunoblots were scanned using the Molecular Imager Chemidoc XRS+ (Bio-Rad). Relative quantification was obtained by dividing the densitometric values of the proteins of interest by the densitometric values obtained with Ponceau red staining for the corresponding lane.

\section{Total RNA extraction and qPCR}

Total RNA was extracted from kidneys with Trizol according manufacturer's protocol (Life Technologies). Reverse transcription was performed on $1 \mu \mathrm{g}$ of total RNA with the ImProm-IITM Reverse Transcription System (Promega). Relative abundances of transcripts were calculated after qPCR amplification. Primers and probe number (corresponding to the Universal ProbeLibrary (Roche)), targeting transcripts of interest and described in Table 1, were designed using ProbeFinder software (Roche).

\section{Statistics}

Results are expressed as means \pm SEM from several animals. Two-way ANOVA, one-way ANOVA followed by Bonferroni's post-test or Student's $t$ test were used
Fig. 1 Evolution of body weight after bile duct ligation of CTL (a) or $\alpha \mathrm{ENaC} \mathrm{KO}(\mathbf{b})$ mice without $(\mathrm{BDL}-)$ and with $(\mathrm{BDL}+)$ ascites. The number of animals weighed is indicated in tables underneath (BDL bile duct ligation). Fate of mice after bile duct ligation (c). Indirect quantification of ascites accumulation rate six CTL and five $\mathrm{KO}$ mice (d). Values are expressed as mean $\pm \mathrm{SEM}$
A

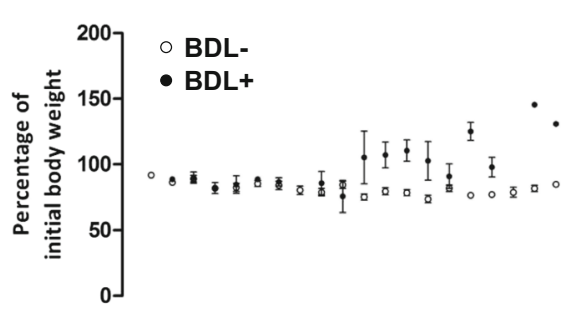

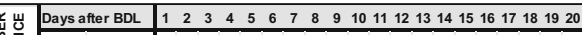

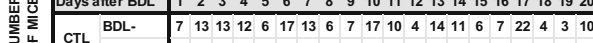

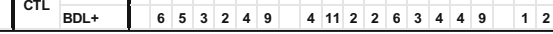

C

FATE OF MICE AFTER BILE DUCT LIGATION

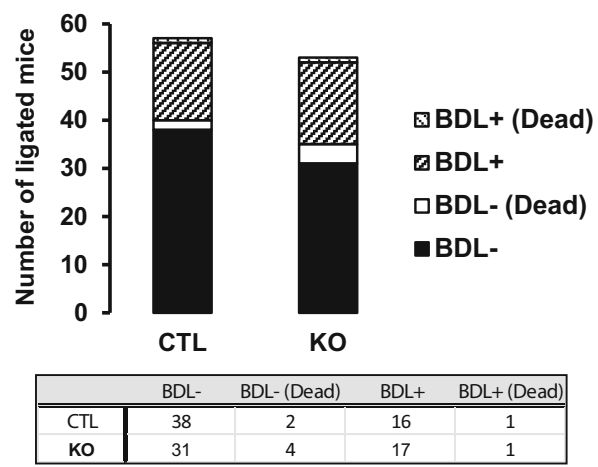

B BODY WEIGHT (KO)

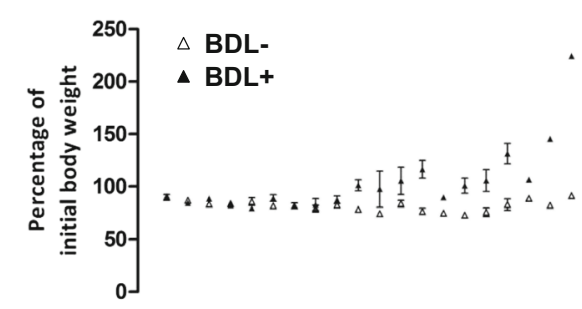

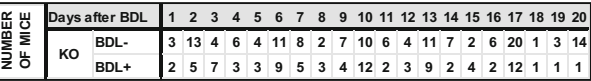

D INDIRECT QUANTIFICATION OF ASCITES ACCUMULATION RATE

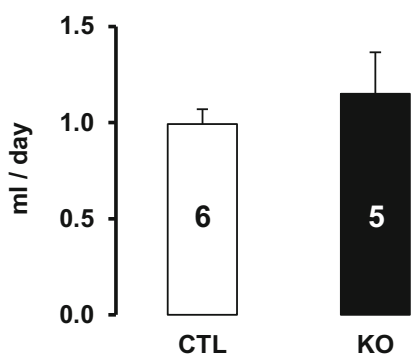


Fig. 2 Renal immunolocalization of $\alpha \mathrm{ENaC}$ for SHAM, $\mathrm{BDL}-$ and $\mathrm{BDL}+$ mice. Collecting ducts $(C)$, proximal tubules $(P)$

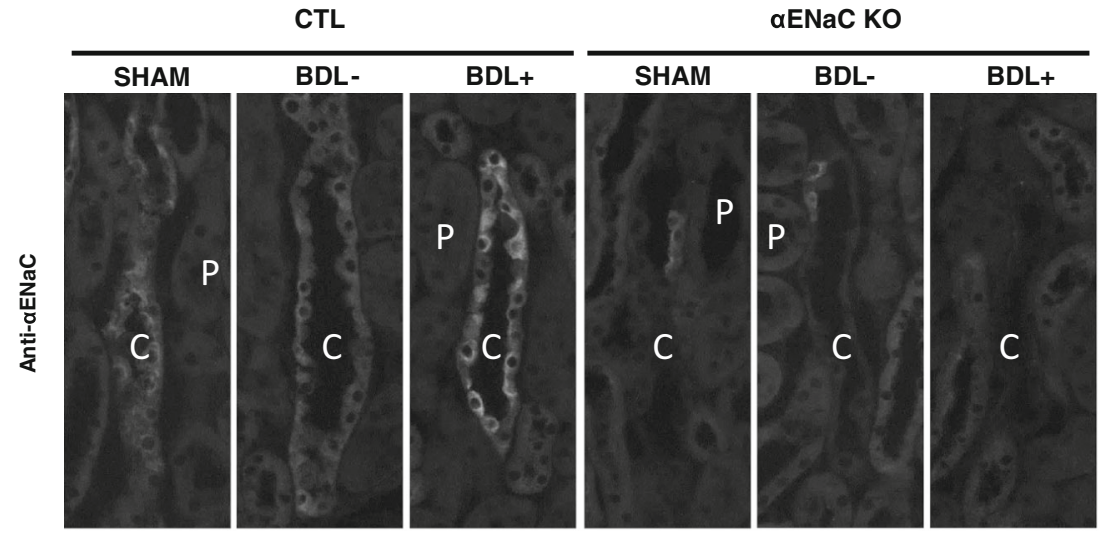

to determine statistical differences. A two-sample test for the equality of proportions was used to analyse the fate of mice after bile duct ligation.

\section{Results}

\section{Control and collecting duct alpha ENaC KO mice develop ascites}

The presence of ascites was a prerequisite to identify cirrhotic mice with sodium retention. Ascites development was indirectly estimated by body weight measurement over 20 days following surgery (Fig. 1a, b). Around 10 days after BDL, $30 \%$ of CTL (17 out of 57) and $34 \%$ of KO (18 out of 53) of bile duct-ligated mice rapidly gained weight due to ascites accumulation $(\mathrm{BDL}+)$. Mice were sacrificed when ascites was observed for several consecutive days. The proportion of mice developing ascites and their survival rate after bile duct ligation were not affected by the genotype $(p=0.79)$ (Fig. 1c). Ascites accumulated at $1 \mathrm{ml}$ per day, and its volume reached about $10 \mathrm{ml}$ at the time of sacrifice (Fig. 1d). Mice which did not gain weight over a period of 20 to 30 days after BDL were sacrificed and considered to be mice with compensated cirrhosis (BDL-).
Fig. 3 Urinary $\mathrm{Na}^{+}, \mathrm{K}^{+}$/ creatinine and $\mathrm{Na}^{+} / \mathrm{K}^{+}$ratio and plasma aldosterone concentrations. Urinary $\mathrm{Na}^{+} /$ creatinine (a). Urinary $\mathrm{K}^{+}$/ creatinine (b). Urinary $\mathrm{Na}^{+} / \mathrm{K}^{+}$ ratio of $\mathrm{CTL}$ and $\mathrm{KO}$ mice: without ascites, more than 2 weeks after bile duct ligation (BDL-) and with ascites, more than 2 weeks after bile duct ligation $(\mathrm{BDL}+)(\mathbf{c})$. Aldosterone plasma concentrations of CTL and KO mice: sham-operated (SHAM), without (BDL-) and with $(\mathrm{BDL}+)$ ascites (d). Values are expressed as mean \pm SEM.

* Significant differences were revealed by two-way ANOVA followed by Bonferroni's posttest
A

URINARY $\mathrm{Na}^{+} /$Creatinine

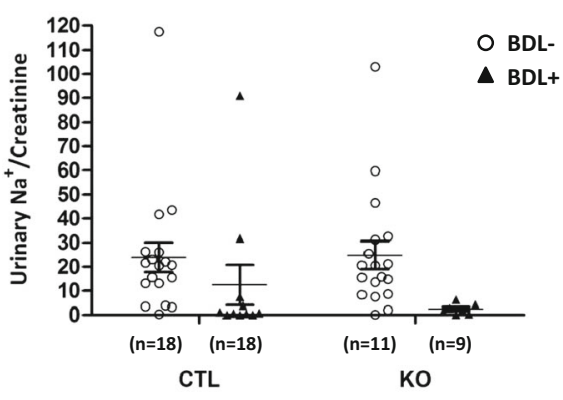

C

URINARY $\mathrm{Na}^{+} / \mathrm{K}^{+}$

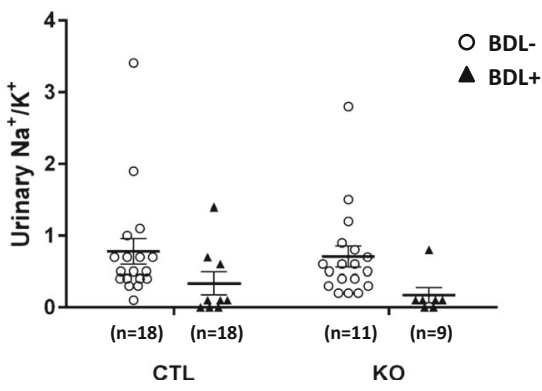

B

URINARY K+ / Creatinine

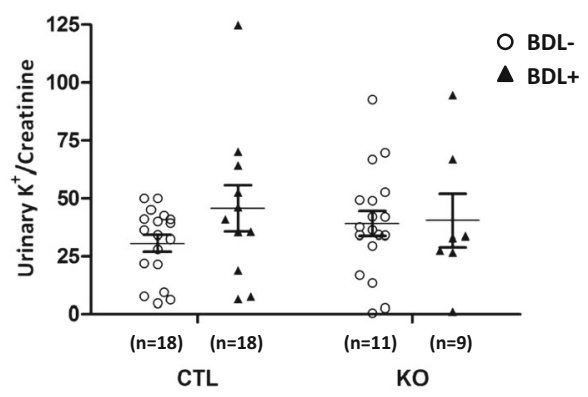

D ALdOSTERONE PLASMA CONCENTRATIONS

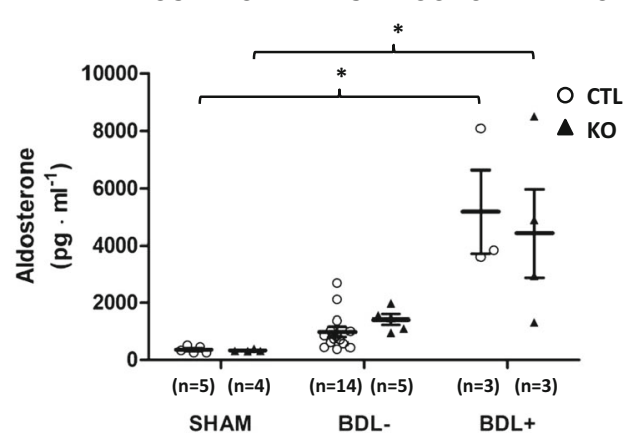




\section{Immunolocalization confirms $\alpha \mathrm{ENaC}$ disruption in CDs}

Deletion of $\alpha \mathrm{ENaC}$ along $\mathrm{CDs}$ of $\alpha \mathrm{ENaC} \mathrm{KO}$ mice was assessed by immunostaining (Fig. 2). In CTL mice, $\alpha \mathrm{ENaC}$ was seen in all principal cells of CDs, independent from the group (SHAM, BDL- and BDL + ). In $\mathrm{KO}$ mice, $\alpha \mathrm{ENaC}$ was absent from $C D$ cells. A very few principal cells with remaining $\alpha \mathrm{ENaC}$ expression were seen in the initial cortical collecting duct.

\section{Urinary sodium and potassium excretion are similar in CTL and $\alpha \mathrm{ENaC} \mathrm{KO}$ mice}

As expected in mice retaining sodium, we observed a significant reduction of the urinary $\mathrm{Na}^{+}$/creatinine (two-way ANOVA with genotype and presence of ascites as factors: interaction, $p=$ not significant (ns); genotype, $p=\mathrm{ns}$; presence of ascites, $p=0.0217$ ) (Fig. $3 \mathrm{a}$ ) and of the urinary $\mathrm{Na}^{+} / \mathrm{K}^{+}$ratio (two-way ANOVA: interaction, $p=\mathrm{ns}$; genotype, $p=\mathrm{ns}$;
Fig. $4 \propto \mathrm{ENaC}$ abundance. Membrane protein extracts from whole kidneys from CTL $(n=4)$ and $\mathrm{KO}(n=4)$ mice were loaded on a single $10 \%$ polyacrylamide gel (a) and quantified. Abundance of the total $\alpha \mathrm{ENaC}$ protein (b). Abundance of the full $\alpha \mathrm{ENaC}$ protein $(\mathbf{c})$. Abundance of the $\alpha \mathrm{ENaC}$ cleaved protein $(\mathbf{d})$. Abundance of $\alpha \mathrm{ENaC}$ transcript (scnn1a) (e). Values are expressed as mean \pm SEM. * Significant differences were revealed by twoway ANOVA followed by Bonferroni's post-test

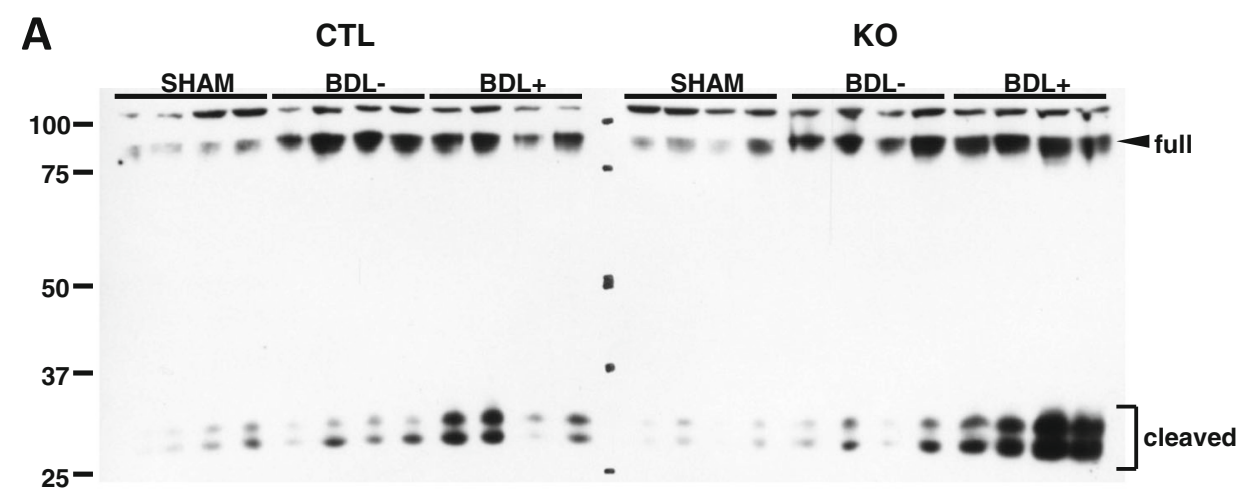

B

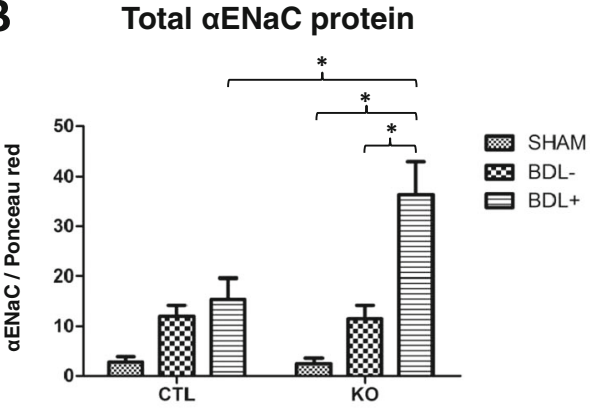

C

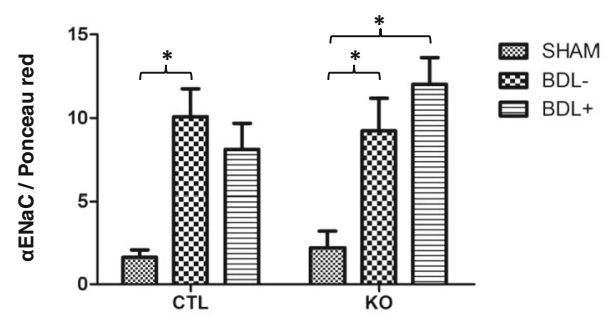

D Cleaved $\alpha E N a C$ protein

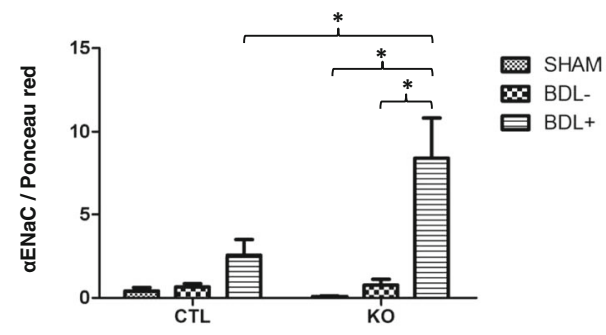

E aENaC (scnn1a) transcript

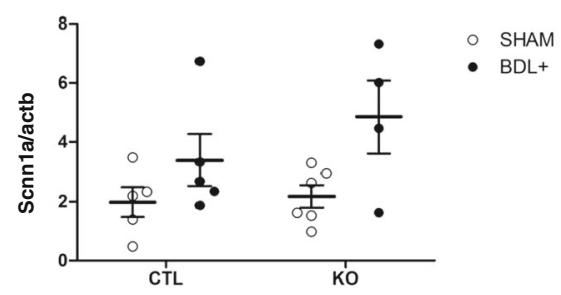


presence of ascites, $p=0.0133$ ) (Fig. $3 \mathrm{c}$ ). The urinary $\mathrm{K}^{+} /$creatinine (Fig. 3b) remained unchanged.

\section{Plasma aldosterone concentrations increase in CTL and $\alpha \mathrm{ENaC} \mathrm{KO}$ mice with ascites}

Plasma aldosterone concentrations increased independently of genotypes following bile duct ligation (two-way ANOVA with health status: SHAM, BDL-, BDL+ and genotype as factors: interaction, $p=\mathrm{ns}$; genotype, $p=\mathrm{ns}$; presence of ascites, $p<0.0001$ ) (Fig. 3d); the difference between SHAM and BDL- group was not significant.

\section{$\mathrm{ENaC}$ is upregulated in cirrhotic CTL and $\mathrm{KO}$ mice}

Immunoblots on membrane proteins extracted from kidney homogenates showed increased $\alpha \mathrm{ENaC}$ abundance in cirrhotic mice (BDL- or BDL+) (Fig. 4a). The cleaved form of $\alpha \mathrm{ENaC}$ appeared as doublets, as previously observed by others $[6,10,11]$. Statistical analysis of band density quantifications revealed (Fig. 4b) an upregulation of total $\alpha \mathrm{ENaC}$ (full and cleaved forms) (two-way ANOVA with health status: SHAM, BDL- and BDL+ and genotype as factors: interaction, $p=0.0107$; genotype, $p=0.0348$; bile duct ligation, $p<0.0001$-Bonferroni's post-test: KO SHAM vs KO
$\mathrm{BDL}+, p<0.0001 ; \mathrm{KO} \mathrm{BDL}^{-}$vs $\mathrm{KO} \mathrm{BDL}+, p=0.0017$; $\mathrm{CTL} \mathrm{BDL}+\mathrm{vs} \mathrm{KO} \mathrm{BDL}+p=0.0096$ ).

Analysis of the $\alpha \mathrm{ENaC}$ full form showed an increase in BDL - mice (two-way ANOVA: interaction=ns; genotype, $p=$ ns; bile duct ligation, $p<0.0001-$ Bonferroni's post-test: CTL SHAM vs CTL BDL-, $p=0.0107$, KO SHAM vs KO $\mathrm{BDL}-, p=0.0498$ and $\mathrm{KO}$ SHAM vs KO BDL,$+ p=0.0025$ ) (Fig. 4c).

An increase of the $\alpha \mathrm{ENaC}$ cleaved form was observed in ascitic mice; however, it was significant only in the KO BDL+ likely due to the variability observed in CTL BDL+ mice (two-way ANOVA: interaction, $p=0.0175$; genotype, $p=$ 0.0462 ; bile duct ligation, $p=0.0002$ - Bonferroni's post-test: KO SHAM vs KO BDL-, $p=0.0005$; KO SHAM vs KO $\mathrm{BDL}+, p=0.0014$; $\mathrm{CTL} \mathrm{BDL}+\mathrm{vs} \mathrm{KO} \mathrm{BDL}+, p=0.018$ ) (Fig. 4d). The abundance of $\alpha \mathrm{ENaC}$ transcript (scnnla) was affected in BDL + mice independently of genotypes (two-way ANOVA: interaction, $p=\mathrm{ns}$; genotype, $p=\mathrm{ns}$, bile duct ligation, $p=0.0133$ ) (Fig. 4e). The expression of $\beta \mathrm{ENaC}$ subunit is illustrated in Fig. 5a (two-way ANOVA: interaction, $p=$ 0.0169 ; genotype, $p=\mathrm{ns}$; bile duct ligation $p<0.0001-$ Bonferroni's post-test: KO SHAM vs KO BDL- $-p<0.0003$; $\mathrm{KO} \mathrm{BDL}-$ vs KO BDL,$+ p=0.0001$; CTL BDL - vs KO BDL ,$- p=0.0375$ ) (Fig. 5b). The abundance of $\beta \mathrm{ENaC}$ transcript (scnn1b) was affected by the bile duct ligation (two-way
Fig. $5 \beta \mathrm{ENaC}$ abundance. Membrane protein extracts from whole kidneys from CTL $(n=4)$ and $\mathrm{KO}(n=4)$ mice were loaded on a single $10 \%$ polyacrylamide gel (a) and quantified. Abundance of $\beta \mathrm{ENaC}$ protein (b).

Abundance of $\beta \mathrm{ENaC}$ transcript (scnn1b) abundance (c). Values are expressed as mean \pm SEM. * Significant differences were revealed by two-way ANOVA followed by Bonferroni's posttest

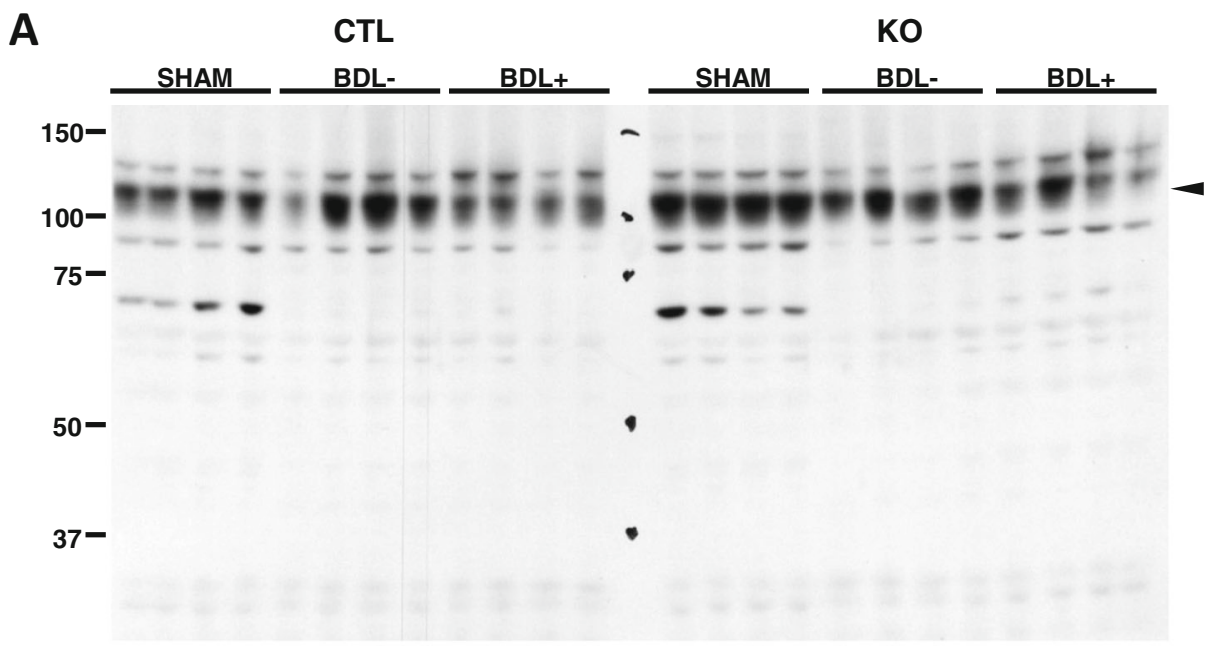

B $\beta E N a C$ protein C $\beta E N a C$ (scnn1b) transcript
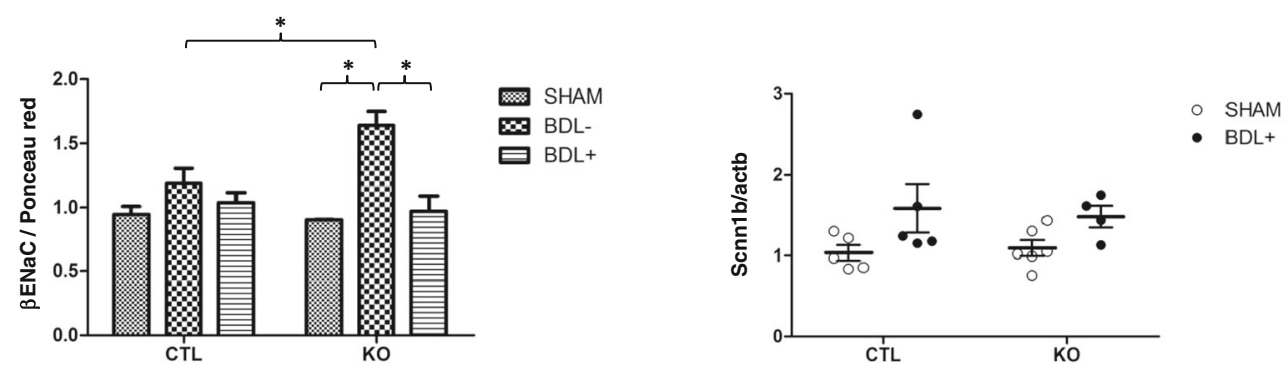
ANOVA: interaction, $p=\mathrm{ns}$; genotype, $p=\mathrm{ns}$, bile duct ligation, $p=0.0185$ ) (Fig. 5c).

Immunoblots showed a higher abundance of the $\gamma \mathrm{ENaC}$ cleaved form compared to its full form for two CTL BDL+ and $\mathrm{KO} \mathrm{BDL}+$ mice and the quasi absence of the $\gamma \mathrm{ENaC}$ cleaved form in BDL- (Fig. 6a). No differences were seen in the total $\gamma \mathrm{ENaC}$ protein (full and cleaved). The full $\gamma \mathrm{ENaC}$ was less abundant in BDL+ than in BDL- in both genotypes

A
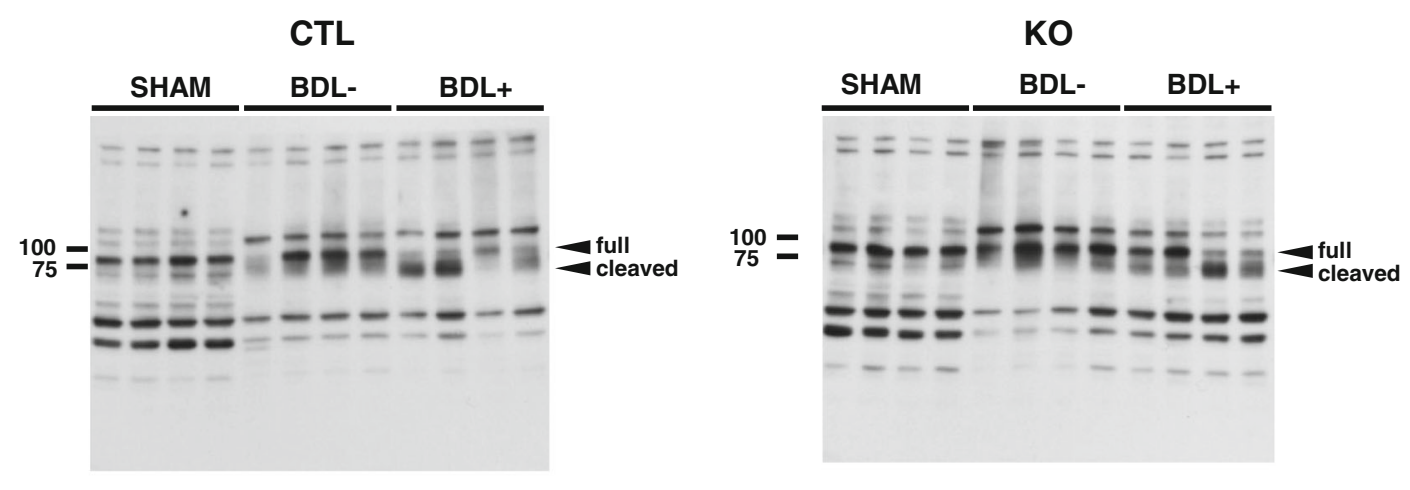

B

Total yENaC protein

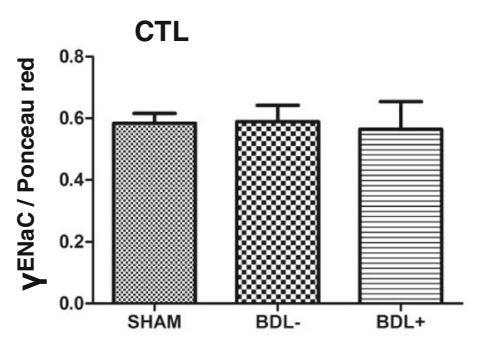

KO

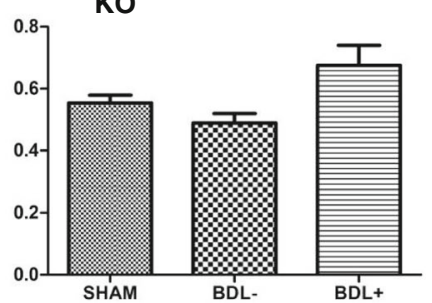

E YENaC (scnn1g) transcript

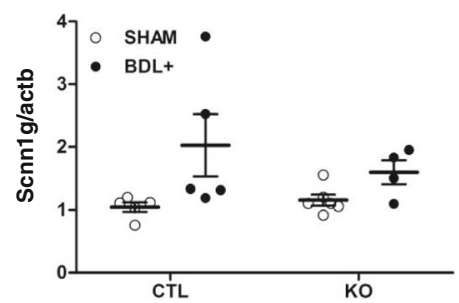

C Full yENaC protein
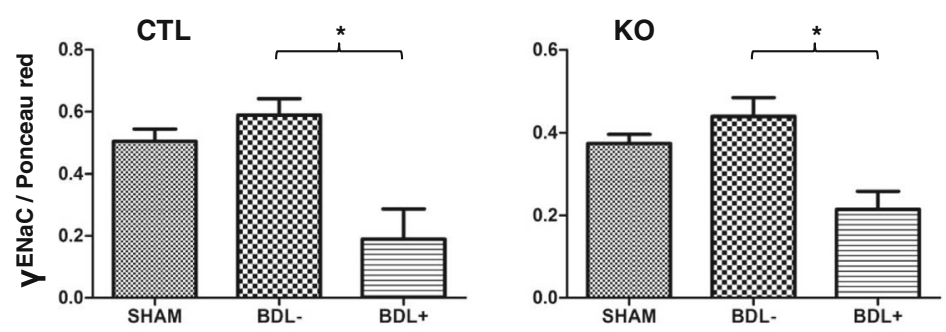

D

\section{Cleaved YENaC protein}
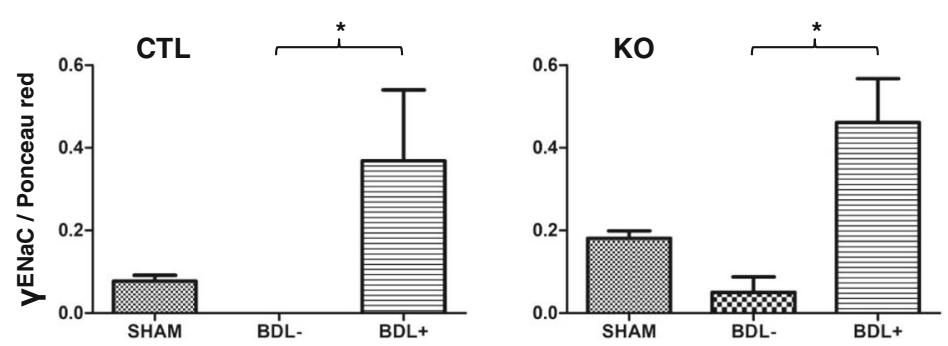

Fig. $6 \gamma \mathrm{ENaC}$ abundance. Membrane protein extracts from whole kidneys CTL $(n=4)$ of and KO $(n=4)$ of mice were loaded on two protein (c); abundance of the cleaved $\gamma \mathrm{ENaC}$ protein $(\mathbf{d})$; abundance of
$\gamma \mathrm{ENaC}$ transcript $(\mathrm{scnn} 1 \mathrm{~g})(\mathbf{e})$. Values are expressed as mean $\pm \mathrm{SEM}$. different 4-20\% polyacrylamide gels (a). Abundance of the total $\gamma \mathrm{ENaC}$ protein (full and cleaved) (b); abundance of the full $\gamma \mathrm{ENaC}$

*Significant differences were revealed by one-way ANOVA followed by Bonferroni's post-test 
(one-way ANOVA, Bonferroni's post-test: CTL BDL- vs CTL BDL+, adj. $p=0.0134$; KO BDL- vs $\mathrm{KO} \mathrm{BDL}+$, adj. $p=0.0243$ ) (Fig. 6c) while $\gamma \mathrm{ENaC}$ cleaved form was more abundant in BDL+ than in BDL- mice (one-way ANOVA, Bonferroni's post-test: CTL BDL- vs CTL BDL+, adj. $p=$ 0.044; KO BDL- vs KO BDL+, adj. $p=0.0098$ ) (Fig. 6d). The abundance of $\gamma \mathrm{ENaC}$ transcript (scnn1g) was affected by the bile duct ligation (two-way ANOVA: interaction, $p=$ ns; genotype, $p=\mathrm{ns}$, bile duct ligation, $p=0.0185$ ) (Fig. 6e).

\section{The absence of ENaC activity in collecting ducts does not influence $\mathrm{Na}, \mathrm{K}$-ATPase abundance}

Previously used as a marker for sodium reabsorption along renal tubules [1], the $\mathrm{Na}, \mathrm{K}$-ATPase activity measurements performed in microdissected tubules at $V_{\text {max }}$ reflects the abundance of $\mathrm{Na}, \mathrm{K}$-ATPase holoenzyme. In this study, the measurements did not reveal differences between groups (Fig. 7).

\section{Sodium chloride cotransporter abundance differs between CTL and KO cirrhotic mice}

Immunoblots on membrane proteins extracted from whole kidney showed the variation of NCC abundance in cirrhotic mice (Fig. 8a). Quantification of band density showed a lower expression of NCC in cirrhotic KO BDL- (one-way ANOVA, Bonferroni's post-test: SHAM vs BDL-, $p=0.0287$ and BDL - vs BDL+, $p=0.0075$ ) (Fig. 8b). Since samples from CTL and $\mathrm{KO}$ were loaded on different gels and thus could not be compared, a second electrophoresis was performed to investigate differences between CTL and KO samples in SHAM, $\mathrm{BDL}-$ and BDL+ (Fig. 9a, b). The abundance of NCC protein was lower in $\mathrm{KO}$ BDL- compared to CTL BDL - (Student's $t$

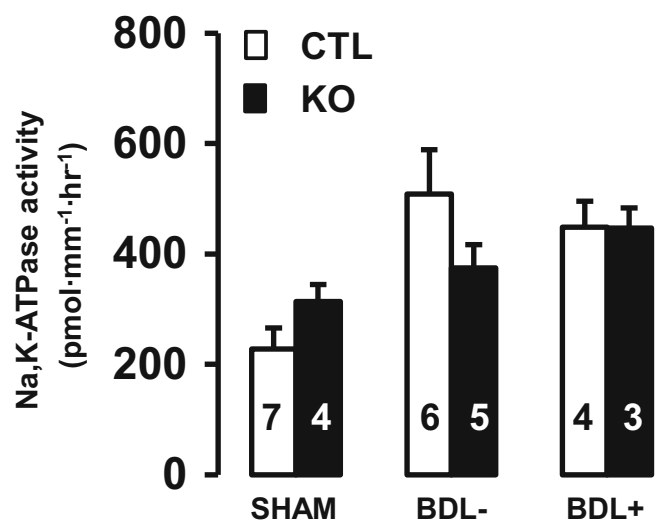

Fig. $7 \mathrm{Na}, \mathrm{K}$-ATPase abundance in cortical collecting ducts. Na,KATPase abundance was quantified by measuring the Na,K-ATPase activity at $V_{\max }$ in microdissected CCDs from CTL and collecting ducts specific $\alpha \mathrm{ENaC} \mathrm{KO}$ mice for the three groups: SHAM-operated, without ascites (BDL-) and with (BDL + ). Values are expressed as mean \pm SEM. The number into the columns represents the $n$ test: $p<0.01)$ but higher in $\mathrm{KO} \mathrm{BDL}+$ compared to $\mathrm{CTL}$ BDL+ (Student's $t$ test: $p<0.01)$.

\section{Discussion}

To our knowledge, this is the first study investigating the mechanisms of sodium retention by bile duct ligation in genetically modified animals. It demonstrated in ascitic mice that the disruption of $\mathrm{ENaC}$ and thus a lack of its activity in $\mathrm{CDs}$ induced $\mathrm{ENaC}$ and NCC in upstream segments. These results on $\mathrm{ENaC}$ expression are in line with previous studies demonstrating the importance of $\mathrm{ENaC}$ in $\mathrm{CNTs}$ for the regulation of sodium reabsorption [9, 12, 27].

The absence of ENaC in CDs did not affect ascites formation. Ascites developed in $30 \%$ of CTL and $34 \%$ of KO after bile duct ligation.

The immunohistochemical studies confirmed the disruption of $\mathrm{ENaC}$ in $\mathrm{CDs}$ of $\mathrm{KO}$ mice. Although a very few single cells in cortical collecting ducts escape the cre recombinase mediated inactivation of $\alpha \mathrm{ENaC}$, as previously reported [30], we consider it highly unlikely that these few single CD cells with persistent $\alpha \mathrm{ENaC}$ expression can account for the absence of differences between CTL and KO mice. It is likely that upstream segments contribute to sodium retention.

The urinary $\mathrm{Na}^{+} /$creatinine as well as $\mathrm{Na}^{+} / \mathrm{K}^{+}$ratios were reduced and plasma aldosterone concentrations increased in BDL+, as observed in humans [4].

Western blot analysis not only showed for both genotypes an increase of $\alpha \mathrm{ENaC}$ abundance in BDL- and BDL+ but it also revealed that the cleavage of $\alpha$ and $\gamma$ subunits was significant only in BDL + mice, which were retaining sodium. In kidneys, $\alpha \mathrm{ENaC}$ protein abundance has been shown to be regulated by aldosterone, while $\beta \mathrm{ENaC}$ and $\gamma \mathrm{ENaC}$ not or only weakly $[6,26]$. Moreover, aldosterone stimulation or low salt diet was shown to induce an apical redistribution of $\alpha \mathrm{ENaC}, \beta \mathrm{ENaC}$ and $\gamma \mathrm{ENaC}[8,10,23,24,26]$ and cleavage of $\alpha \mathrm{ENaC}$ and $\gamma \mathrm{ENaC}[6,26]$. Cleavage of $\mathrm{ENaC}$ by exogenous trypsin has been linked to an increase of channel activity [8, 28]. Kim et al. observed, in ascitic rats, an increased apical targeting of $\alpha \beta \gamma \mathrm{ENaC}$ in DCTs, CNTs and CDs and cleavage of $\gamma \mathrm{ENaC}$, without changes of $\alpha \beta \gamma \mathrm{ENaC}$ protein abundance $[21,20]$. Altogether, these results showed that in ascitic animals, $\alpha$ and $\gamma \mathrm{ENaC}$ are cleaved, suggesting an increase in $\mathrm{ENaC}$ activity and thus demonstrate its importance for sodium retention. Interestingly, in our study, the $\alpha \mathrm{ENaC}$ cleaved form was more abundant in $\mathrm{KO} \mathrm{BDL}+$ than in CTL BDL+ mice, suggesting insufficient sodium reabsorption and a need to compensate.

In contrast to Ackermann et al., we did not observe any significant upregulation of the $\mathrm{Na}, \mathrm{K}$-ATPase activity in isolated CCDs between SHAM-operated and cirrhotic mice [1]. This difference could be due to the mouse strains used. In 
Fig. 8 NCC abundance: comparison between SHAM, BDL- and BDL+. Membrane protein extracts from whole kidneys of CTL $(n=4)$ and $\mathrm{KO}$ $(n=4)$ were loaded on a $10 \%$ polyacrylamide gel (a). NCC protein abundance (b). NCC transcript (sl12a3) abundance transcript (c). Values are

expressed as mean \pm SEM. * Significant differences were revealed by one-way ANOVA followed by Bonferroni's post-test
A

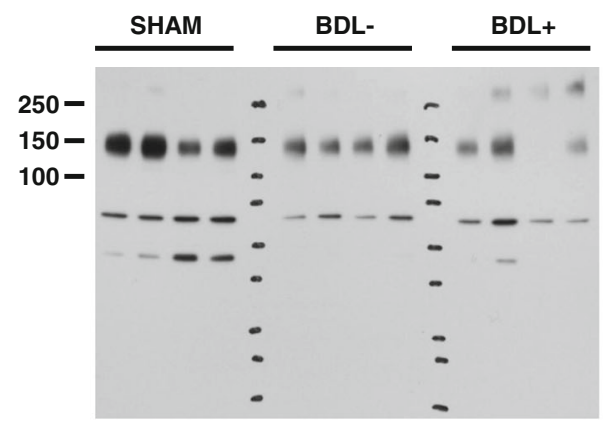

KO

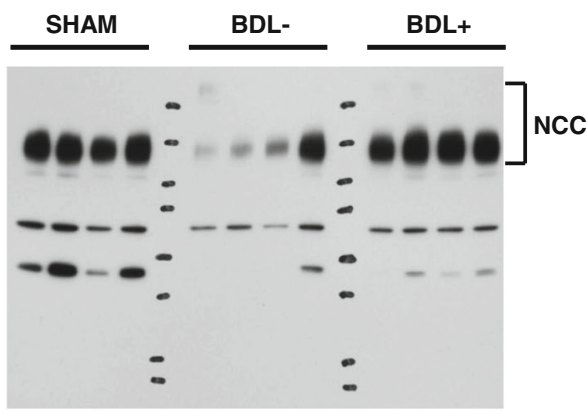

B

NCC protein

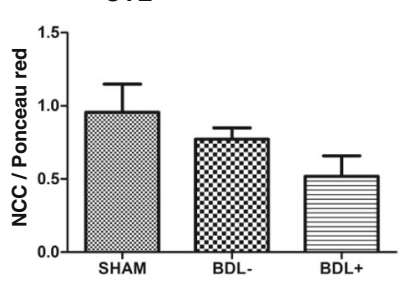

CTL

C NCC (sIc12a3) transcript

Ko

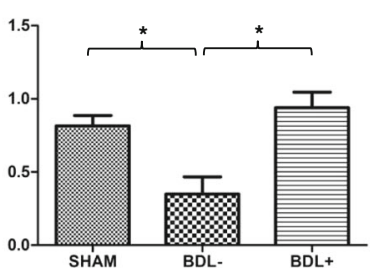

Fig. 9 NCC abundance: comparison between CTL and KO. Membrane protein extracts from whole kidneys SHAM, BDL - and BDL+ were loaded on a $10 \%$ polyacrylamide gel (a) and quantified (b). Values are expressed as mean $\pm \mathrm{SEM}$. *Significant differences were revealed by Student's $t$ test

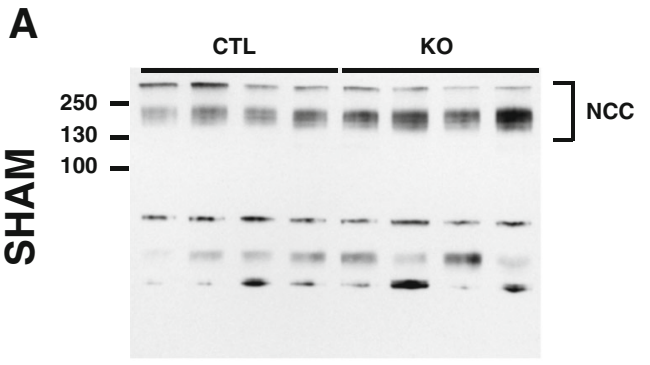

B
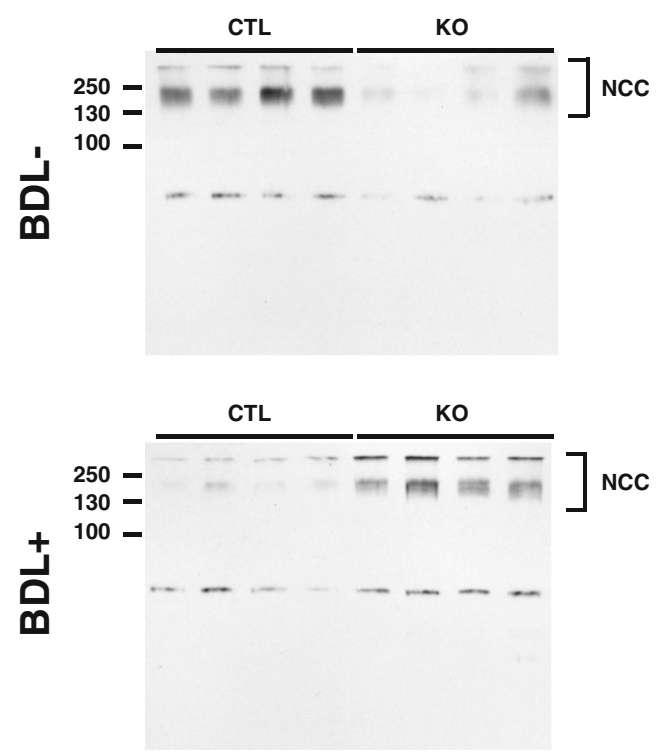

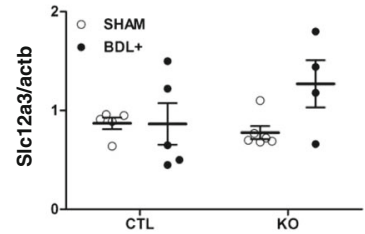

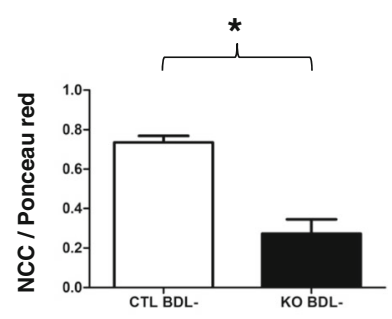

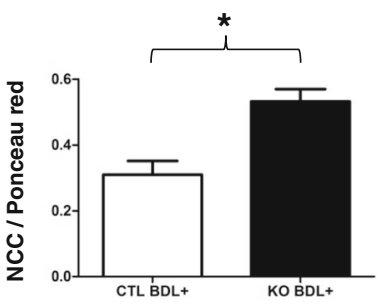


the previous study, $\mathrm{CD} 1$ mice were used whereas in the actual one, we used 129/Sv x C57BL/6, since they are more prone to develop ascites [2]. Additionally, mice were analysed at different time point.

We did not observe an increase in NCC abundance, although NCC is described as an aldosterone-induced protein [19]. The slight decrease in NCC abundance observed in CTL cirrhotic mice was not significant in contrast to what was previously reported $[7,14,35]$. In BDL- mice, NCC protein expression was lower than in SHAM, whereas in BDL+ mice, in which sodium retention occurs, it was higher in KO than CTL mice and probably reached the same level as in the SHAMoperated mice as shown by the results in Fig. 8. These results suggested compensation by NCC of an insufficient $\mathrm{ENaC}$ activity in CDs. The reduced abundance of NCC in non-ascitic mice may reflect the aldosterone escape phenomenon, characterized by a downregulation of NCC in the presence of high plasma aldosterone concentrations and high salt diet [31]. Conditions which are similar to those encountered by the CTL cirrhotic mice, their plasma aldosterone concentrations are high and their salt intake sufficient. The downregulation of NCC could also be due to an increase in plasma potassium concentration [3]. However, this hypothesis is unlikely since several studies performed in rats reported normal plasma potassium values in cirrhotic animals $[14,15,17,18]$.

In summary, our study showed that in pathological conditions such as cirrhosis, the amount of sodium reabsorbed through $\mathrm{ENaC}$ in CDs is likely not negligible and if not sufficient, $\mathrm{ENaC}$ and $\mathrm{NCC}$ upregulation in upstream segments may happen. Similar ENaC upregulation was suggested by results obtained by Ronzaud et al. in $\mathrm{MR}^{\mathrm{AQP} 2 \mathrm{Cre}}$ mice [29]. The upregulation of NCC could explain the blunted natriuretic effect of the amiloride observed in cirrhotic rats treated with amiloride [16].

The control of renal sodium retention and ascites development is not trivial in cirrhotic patients. A better understanding of the mechanisms responsible for renal sodium handling would improve its clinical management. This study illustrates the usability of gene-modified mouse models to dissect the complex mechanisms of sodium retention. It revealed compensation mechanisms which could take place when we downregulate artificially ion transporters, similarly as what is done with diuretics. In conclusion, to develop efficient therapeutic strategies, we have to understand pathways leading to sodium/potassium imbalance and to further consider compensatory mechanisms.

Acknowledgments We thank Professors A Doucet and B Rossier for constructive comments, Dr. H Mistry, Dr. G Crambert and Dr. N Faller for their helpful reading of the manuscript and discussions and A Tedjani and
A Menoud for the technical assistance. We thank Dr. Frederic Schütz (Bioinformatics Core Facility, SIB Swiss Institute of Bioinformatics) for his assistance with statistical analysis.

Financial support This study was supported by grants from the Swiss National Science Foundation: 31003A 120406 and 31003A 135417 attributed to BV. The laboratory of $\overline{\mathrm{JL}}$ is supported by $\mathrm{SNF}$ grant 310030_143929/1.

\section{References}

1. Ackermann D, Mordasini D, Cheval L, Imbert-Teboul M, Vogt B, Doucet A (2007) Sodium retention and ascites formation in a cholestatic mice model: role of aldosterone and mineralocorticoid receptor? Hepatology 46:173-179. doi:10.1002/hep.21699

2. Alaish SM, Torres M, Ferlito M, Sun CC, De Maio A (2005) The severity of cholestatic injury is modulated by the genetic background. Shock 24:412-416

3. Ananthanarayanan M, Balasubramanian N, Makishima M, Mangelsdorf DJ, Suchy FJ (2001) Human bile salt export pump promoter is transactivated by the farnesoid $\mathrm{X}$ receptor/bile acid receptor. J Biol Chem 276:28857-28865. doi:10.1074/jbc. M011610200

4. Arroyo V, Bernardi M, Epstein M, Henriksen JH, Schrier RW, Rodes J (1988) Pathophysiology of ascites and functional renal failure in cirrhosis. J Hepatol 6:239-257

5. Doucet A, Katz AI, Morel F (1979) Determination of Na-K-ATPase activity in single segments of the mammalian nephron. Am J Physiol 237:F105-113

6. Ergonul Z, Frindt G, Palmer LG (2006) Regulation of maturation and processing of ENaC subunits in the rat kidney. Am J Physiol Renal Physiol 291:F683-693. doi:10.1152/ajprenal.00422.2005

7. Fernandez-Llama P, Jimenez W, Bosch-Marce M, Arroyo V, Nielsen S, Knepper MA (2000) Dysregulation of renal aquaporins and $\mathrm{Na}-\mathrm{Cl}$ cotransporter in CCl4-induced cirrhosis. Kidney Int 58: 216-228. doi:10.1046/j.1523-1755.2000.00156.x

8. Frindt G, Ergonul Z, Palmer LG (2008) Surface expression of epithelial Na channel protein in rat kidney. J Gen Physiol 131:617627. doi:10.1085/jgp.200809989

9. Frindt G, Palmer LG (2004) Na channels in the rat connecting tubule. Am J Physiol Renal Physiol 286:F669-674. doi:10.1152/ ajprenal.00381.2003

10. Frindt G, Palmer LG (2009) Surface expression of sodium channels and transporters in rat kidney: effects of dietary sodium. Am J Physiol Renal Physiol 297:F1249-1255. doi:10.1152/ajprenal. 00401.2009

11. Frindt G, Palmer LG (2012) Regulation of epithelial Na+ channels by adrenal steroids: mineralocorticoid and glucocorticoid effects. Am J Physiol Renal Physiol 302:F20-26. doi:10.1152/ajprenal. 00480.2011

12. Fu Y, Gerasimova M, Batz F, Kuczkowski A, Alam Y, Sanders PW, Ronzaud C, Hummler E, Vallon V (2015) PPARgamma agonistinduced fluid retention depends on alphaENaC expression in connecting tubules. Nephron 129:68-74. doi:10.1159/000370254

13. Gines P, Cardenas A, Arroyo V, Rodes J (2004) Management of cirrhosis and ascites. N Engl J Med 350:1646-1654. doi:10.1056/ NEJMra035021

14. Graebe M, Brond L, Christensen S, Nielsen S, Olsen NV, Jonassen TE (2004) Chronic nitric oxide synthase inhibition exacerbates renal dysfunction in cirrhotic rats. Am J Physiol Renal Physiol 286: F288-297. doi:10.1152/ajprenal.00089.2003

15. Jonassen TE, Brond L, Torp M, Graebe M, Nielsen S, Skott O, Marcussen N, Christensen S (2003) Effects of renal denervation 
on tubular sodium handling in rats with CBL-induced liver cirrhosis. Am J Physiol Renal Physiol 284:F555-563. doi:10.1152/ ajprenal.00258.2002

16. Jonassen TE, Heide AM, Janjua NR, Christensen S (2002) Collecting duct function in liver cirrhotic rats with early sodium retention. Acta Physiol Scand 175:237-244

17. Jonassen TE, Marcussen N, Haugan K, Skyum H, Christensen S, Andreasen F, Petersen JS (1997) Functional and structural changes in the thick ascending limb of Henle's loop in rats with liver cirrhosis. Am J Physiol 273:R568-577

18. Jonassen TE, Nielsen S, Christensen S, Petersen JS (1998) Decreased vasopressin-mediated renal water reabsorption in rats with compensated liver cirrhosis. Am J Physiol 275:F216-225

19. Kim GH, Masilamani S, Turner R, Mitchell C, Wade JB, Knepper MA (1998) The thiazide-sensitive $\mathrm{Na}-\mathrm{Cl}$ cotransporter is an aldosterone-induced protein. Proc Natl Acad Sci U S A 95: 14552-14557

20. Kim SW, Wang W, Nielsen J, Praetorius J, Kwon TH, Knepper MA, Frokiaer J, Nielsen S (2004) Increased expression and apical targeting of renal $\mathrm{ENaC}$ subunits in puromycin aminonucleosideinduced nephrotic syndrome in rats. Am J Physiol Renal Physiol 286:F922-935. doi:10.1152/ajprenal.00277.2003

21. Kim SW, Wang W, Sassen MC, Choi KC, Han JS, Knepper MA, Jonassen TE, Frokiaer J, Nielsen S (2006) Biphasic changes of epithelial sodium channel abundance and trafficking in common bile duct ligation-induced liver cirrhosis. Kidney Int 69:89-98. doi:10.1038/sj.ki.5000018

22. Loffing J, Loffing-Cueni D, Valderrabano V, Klausli L, Hebert SC, Rossier BC, Hoenderop JG, Bindels RJ, Kaissling B (2001) Distribution of transcellular calcium and sodium transport pathways along mouse distal nephron. Am J Physiol Renal Physiol 281: F1021-1027

23. Loffing J, Pietri L, Aregger F, Bloch-Faure M, Ziegler U, Meneton P, Rossier BC, Kaissling B (2000) Differential subcellular localization of $\mathrm{ENaC}$ subunits in mouse kidney in response to high- and low-Na diets. Am J Physiol Renal Physiol 279:F252-258

24. Loffing J, Zecevic M, Feraille E, Kaissling B, Asher C, Rossier BC, Firestone GL, Pearce D, Verrey F (2001) Aldosterone induces rapid apical translocation of $\mathrm{ENaC}$ in early portion of renal collecting system: possible role of SGK. Am J Physiol Renal Physiol 280: F675-682

25. Martin PY, Gines P, Schrier RW (1998) Nitric oxide as a mediator of hemodynamic abnormalities and sodium and water retention in cirrhosis. N Eng1 J Med 339:533-541. doi:10.1056/ NEJM199808203390807

26. Masilamani S, Kim GH, Mitchell C, Wade JB, Knepper MA (1999) Aldosterone-mediated regulation of $\mathrm{ENaC}$ alpha, beta, and gamma subunit proteins in rat kidney. J Clin Invest 104:R19-23. doi:10. 1172/JCI7840

27. Meneton P, Loffing J, Warnock DG (2004) Sodium and potassium handling by the aldosterone-sensitive distal nephron: the pivotal role of the distal and connecting tubule. Am J Physiol Renal Physiol 287:F593-601. doi:10.1152/ajprenal.00454.2003

28. Nesterov V, Dahlmann A, Bertog M, Korbmacher C (2008) Trypsin can activate the epithelial sodium channel $(\mathrm{ENaC})$ in microdissected mouse distal nephron. Am J Physiol Renal Physiol 295:F10521062. doi:10.1152/ajprenal.00031.2008

29. Ronzaud C, Loffing J, Bleich M, Gretz N, Grone HJ, Schutz G, Berger $S$ (2007) Impairment of sodium balance in mice deficient in renal principal cell mineralocorticoid receptor. J Am Soc Nephrol 18:1679-1687. doi:10.1681/ASN.2006090975

30. Rubera I, Loffing J, Palmer LG, Frindt G, Fowler-Jaeger N, Sauter D, Carroll T, McMahon A, Hummler E, Rossier BC (2003) Collecting duct-specific gene inactivation of alphaENaC in the mouse kidney does not impair sodium and potassium balance. $\mathrm{J}$ Clin Invest 112:554-565. doi:10.1172/JCI16956

31. Sandberg MB, Maunsbach AB, McDonough AA (2006) Redistribution of distal tubule $\mathrm{Na}+-\mathrm{Cl}-$ cotransporter $(\mathrm{NCC})$ in response to a high-salt diet. Am J Physiol Renal Physiol 291: F503-508. doi:10.1152/ajprenal.00482.2005

32. Schneider CA, Rasband WS, Eliceiri KW (2012) NIH Image to ImageJ: 25 years of image analysis. Nat Methods 9:671-675

33. Sorensen MV, Grossmann S, Roesinger M, Gresko N, Todkar AP, Barmettler G, Ziegler U, Odermatt A, Loffing-Cueni D, Loffing J (2013) Rapid dephosphorylation of the renal sodium chloride cotransporter in response to oral potassium intake in mice. Kidney Int 83:811-824. doi:10.1038/ki.2013.14

34. Wagner CA, Loffing-Cueni D, Yan Q, Schulz N, Fakitsas P, Carrel M, Wang T, Verrey F, Geibel JP, Giebisch G, Hebert SC, Loffing J (2008) Mouse model of type II Bartter's syndrome. II. Altered expression of renal sodium- and water-transporting proteins. Am J Physiol Renal Physiol 294:F1373-1380. doi:10.1152/ajprenal. 00613.2007

35. Yu Z, Serra A, Sauter D, Loffing J, Ackermann D, Frey FJ, Frey BM, Vogt B (2005) Sodium retention in rats with liver cirrhosis is associated with increased renal abundance of $\mathrm{NaCl}$ cotransporter (NCC). Nephrol Dial Transplant 20:1833-1841. doi:10.1093/ndt/gfh916 